\title{
Development and Role of the Subsistence Minimum in the Payrolls Legislation in Slovakia from year 1993
}

\author{
Zuzana Kubaščíková ${ }^{1, *}$, Zuzana Juhaszová ${ }^{1}$, Miloš Tumpach ${ }^{1}$, and Renáta Stanley ${ }^{1}$ \\ ${ }^{1}$ University of Economics in Bratislava, Faculty of Business Informatics, Department of Accounting \\ and Auditing, Dolnozemská 1, 85235 Bratislava, Slovakia
}

\begin{abstract}
Research background: The subsistence minimum category is used in the Slovak Republic in determining several wage and tax categories. In this paper I analyze whether the set standard of living is sufficient with regard to the development of the average wage since 1993 to the present day. Subsequently, the quantities that are based on the subsistence level - nontaxable amounts of the taxpayers' tax base are also analyzed. The results of the analysis show that the distance between the subsistence level and the level of non-taxable parts has gradually increased. The topic of payrolls and related wage variables is a complex and ever-changing topic. Not many authors in Slovakia pay attention to it, and due to constant changes in the given area, the findings of publications and papers is also limited.

Purpose of the article: This paper deals with general theoretical, legal and historical starting points and links between non-taxable parts and the subsistence minimum. The paper presents a cross-section of the history of the application of non-taxable parts in the Slovak Republic.

Methods: The method used in the paper is that of hypotheses determination and testing.

Findings \& Value added: This paper also analyzes the state of national regulation and development trends in the area. In addition to constructive criticism, the article also contains suggestions for improving the current situation.
\end{abstract}

Keywords: average wage, minimal wage, nontaxable parts, subsistence minimum

JEL Classification: $J 30 ; J 80$

\section{Introduction}

The determination of the subsistence minimum is not only related to the setting of the system of social benefits for persons with insufficient income (Zeytinoglu and Akarim,

${ }^{*}$ Corresponding author: zuzana.kubascikova@euba.sk 
2013) but also to the determination of tax quantities - tax bonuses for children and the determination of the non-taxable part (Aujean, 2014).

Many authors in Slovakia and in the world have addressed the topic of the subsistence minimum. In their publication, the authors (Filipová and Valná, 1999) defined the subsistence minimum as the poverty line, while the calculation of the adequate minimum amount of consumption was influenced by the minimum consumer shopping basket. In Slovakia, the importance of the subsistence minimum category increased after 1989, when a minimum amount was set to be guaranteed by the state to the population in order to sustain a dignified life without suppressing the incentive to work (Saric, 2014)

Act no. 463/1991 Coll. defines the subsistence minimum as "the socially recognized minimum limit of a citizen's income, under which a state of material deprivation occurs." This law stipulated the amount of the subsistence minimum per citizen (according to age) and per household (according to the number of household members). The amount of the subsistence minimum under this Act was reassessed when the index of living costs of households in the low-income band increased by at least $10 \%$ following the previous valorization.

Act no. 125/1998 Coll. on the subsistence minimum, he has already set the amounts of the subsistence minimum differently, distinguished the amount of the subsistence minimum per adult, child and another jointly assessed person (adult or child). The valorization mechanism was set to July 1 th, each year in such a way that the individual amounts of the subsistence minimum are determined by the relevant measures of the Ministry of Labor and Social Affairs of the Slovak Republic. The adjustment of the subsistence minimum amounts is made by multiplying the previous values by the growth rate of net cash income per person (or the growth rate of the cost of living of low-income households) determined by the statistical office.

Act no. 601/2003 Coll. without significant changes in the definition and system for determining the subsistence minimum amounts. Unlike the previous law, it no longer contains amounts for the purposes of state social benefits.

\section{Methodology and Data}

We formulated the following hypotheses:

H1: The subsistence minimun in Slovakia is growing from year 1993 aliqout with the growth of the average wage.

$\mathrm{H} 2$ : The rules for the application of non-taxable parts are clearly defined in Slovakia and non-taxable parts protect the lowest incomes from taxation.

H3: All non-taxable parts are tied to the subsistence level and are grow linearly.

For analysis we used data shown in the following table. The development of the substance minimum from 1993 to 2021 together with the development of the average monthly wage in the Slovak economy. 
Table 1 Monthly subsistence minimum and average gross wage comparison

\begin{tabular}{|c|c|c|c|c|c|}
\hline Year & \begin{tabular}{|c|} 
Monthly \\
subsistence \\
minimum (one \\
adult person)
\end{tabular} & $\begin{array}{l}\text { Average } \\
\text { gross } \\
\text { monthly } \\
\text { wage in } \\
\text { SR } \\
\end{array}$ & $\begin{array}{c}\text { Share of } \\
\text { subsistence } \\
\text { minimum in } \\
\text { average wage } \\
\text { in } \% \\
\end{array}$ & $\begin{array}{c}\text { Year-on-year } \\
\text { growth of the } \\
\text { subsistence } \\
\text { minimum in \% }\end{array}$ & \begin{tabular}{|c|} 
Year-on-year \\
growth of \\
average \\
monthly wage \\
in \% \\
\end{tabular} \\
\hline 1993 & 65,72 & 178,55 & 36,81 & & \\
\hline 1994 & 65,72 & 208,92 & 31,46 & 0,00 & 17,01 \\
\hline 1995 & 72,36 & 238,83 & 30,30 & 10,10 & 14,32 \\
\hline 1996 & 72,36 & 270,66 & 26,74 & 0,00 & 13,33 \\
\hline 1997 & 80,00 & 306,25 & 26,12 & 10,55 & 13,15 \\
\hline 1998 & 99,58 & 332,04 & 29,99 & 24,48 & 8,42 \\
\hline 1999 & 108,21 & 356,10 & 30,39 & 8,67 & 7,25 \\
\hline 2000 & 115,85 & 379,41 & 30,53 & 7,06 & 6,55 \\
\hline 2001 & 125,80 & 410,44 & 30,65 & 8,60 & 8,18 \\
\hline 2002 & 130,45 & 448,48 & 29,09 & 3,69 & 9,27 \\
\hline 2003 & 139,75 & 476,83 & 29,31 & 7,12 & 6,32 \\
\hline 2004 & 152,03 & 525,29 & 28,94 & 8,79 & 10,16 \\
\hline 2005 & 157,01 & 573,39 & 27,38 & 3,28 & 9,16 \\
\hline 2006 & 165,31 & 622,75 & 26,54 & 5,29 & 8,61 \\
\hline 2007 & 170,28 & 668,72 & 25,46 & 3,01 & 7,38 \\
\hline 2008 & 178,92 & 723,03 & 24,75 & 5,07 & 8,12 \\
\hline 2009 & 185,19 & 744,50 & 24,87 & 3,51 & 2,97 \\
\hline 2010 & 185,19 & 769,00 & 24,08 & 0,00 & 3,29 \\
\hline 2011 & 189,83 & 786,00 & 24,15 & 2,51 & 2,21 \\
\hline 2012 & 194,58 & 805,00 & 24,17 & 2,50 & 2,42 \\
\hline 2013 & 198,09 & 824,00 & 24,04 & 1,80 & 2,36 \\
\hline 2014 & 198,09 & 858,00 & 23,09 & 0,00 & 4,13 \\
\hline 2015 & 198,09 & 883,00 & 22,43 & 0,00 & 2,91 \\
\hline 2016 & 198,09 & 912,00 & 21,72 & 0,00 & 3,28 \\
\hline 2017 & 205,07 & 954,00 & 21,50 & 3,52 & 4,61 \\
\hline 2018 & 210,20 & 1013,00 & 20,75 & 2,50 & 6,18 \\
\hline 2019 & 214,83 & 1092,00 & 19,67 & 2,20 & 7,80 \\
\hline 2020 & 218,06 & 1133,00 & 19,25 & 1,50 & 3,75 \\
\hline
\end{tabular}

Source: Own processing on the basis of statistical data

All amounts before 2009 were in SKK but for the purpose of comparison they have been converted into euros at the conversion rate of $30,126 \mathrm{SKK}=1$ eur. 


\section{Results and Discussion}

In table no. 1 we can see that the share of the minimum wage in the average wage in the Slovak Republic since 2001 has been constantly declining. Also, the subsistence minimum does not reflect the growth of the average wage in the national economy of the Slovak Republic at all (Bicekova et al., 2015). The following figure no. 1 shows the growth of the average wage and subsistence level since 1993.

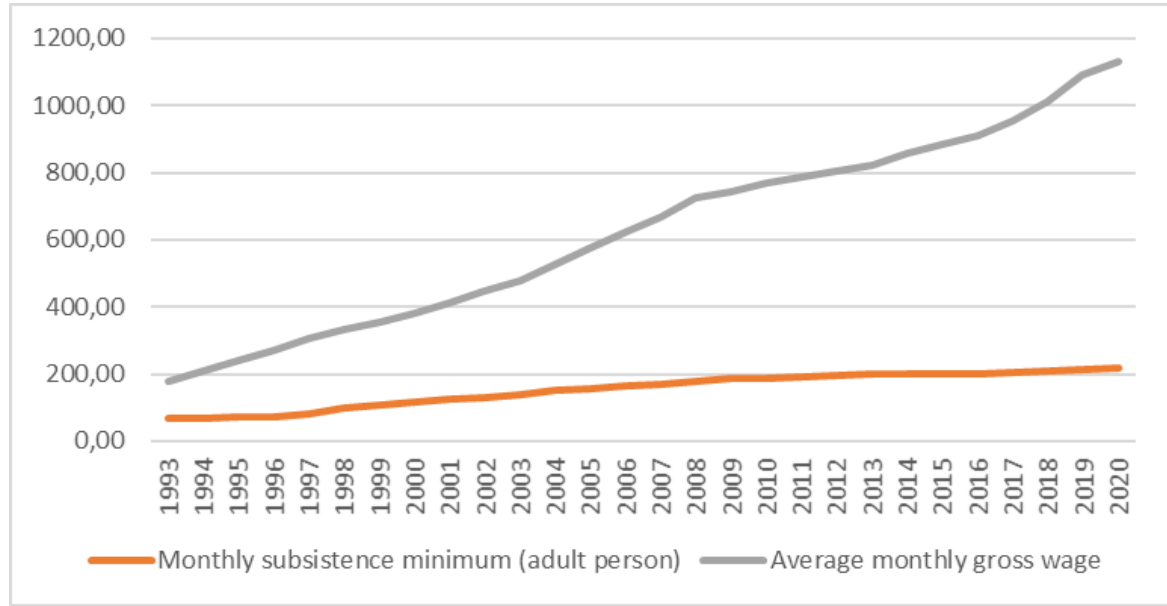

Figure 1. Monthly minimum wage vs. average monthly wage in eur

Source: own processing on the basic of statistical data

The significant items that reduce the tax base for the purposes of calculating income tax are the non-taxable parts. (Zubal'ová, 2019) Just as the rate of personal income tax has changed historically, so have the non-taxable parts affecting the taxpayer's tax base (Bujňáková, 2017). For taxpayers, the application of non-taxable parts means a legal possibility of reducing income tax (vom Berge and Frings, 2020), which they should make full use of. All the non-taxable parts mentioned below are currently (from year 2003) linked to the development of the subsistence minimum.

The non-taxable part for the taxpayer was determined in the years $1993-2003$ to be a fixed amount specified in the Income Tax Act (Mihokova et al., 2018). The non-taxable part could be applied to all the taxpayer's income. The amount of the basic non-taxable amount per taxpayer in 1993 was based on the average subsistence level per individual (the amount of SKK 1 200,- / EUR 39,83 for food, the amount of SKK 500,- / EUR 16,60 per household, ie a total of SKK 1 700,- / EUR 56,43 per month, SKK 20 400,- / EUR 677,16 annually). In 1996, the non-taxable part consisted of the main principles and amounted to SKK 2 180,- / EUR 72,36 per month and SKK 26 160,- / EUR 868,35 per year. The subsistence level in 2000 was SKK 3 490,- / EUR 115,85 per month and SKK 41 880,- / EUR 1390,16 per year. However, the amount of the basic non-taxable amount in 2000 no longer corresponded to the increase in the subsistence minimum (the increase in the subsistence minimum was 5,2\% and the higher amount of the non-taxable part from SKK 20 400,- / EUR 677,16 annually to SKK 21 000,- / EUR 697,07 annually represents an increase of only $2,94 \%$ ). On the contrary, in 2000 the subsistence minimum did not change compared to 1999 (when it remained at the level of SKK 41 880,- / EUR 1390,16), but the amount of the non-taxable part annually per taxpayer in year 2000 had to be from SKK 21 000,- / EUR 697,07 to SKK 38 760,- / EUR 1 286,60. With effect from January 1th, 2004 , it was no longer possible to limit the taxpayer's tax base by the non-taxable part for the taxpayer who is in receipt of an invalidity pension or a partial invalidity pension, resp. 
is severely disabled and the non-taxable part per dependent child (in the case of a child who is severely disabled by twice the set amount).

Table 2 Monthly subsistence minimum and non-taxable parts in eur

\begin{tabular}{|c|c|c|c|c|}
\hline Year & $\begin{array}{c}\text { Monthly } \\
\text { subsistence } \\
\text { minimum (adult } \\
\text { person) } \\
\end{array}$ & $\begin{array}{l}\text { Monthly non- } \\
\text { taxable part } \\
\text { for taxpayer }\end{array}$ & $\begin{array}{l}\text { Monthly non- } \\
\text { taxable part for } \\
\text { child / tax bonus } \\
\text { for child }\end{array}$ & $\begin{array}{c}\text { Annual non- } \\
\text { taxable part for } \\
\text { taxpayer } \\
\text { husband/wife }\end{array}$ \\
\hline 1993 & 65,72 & 56,43 & 3,73 & 398,33 \\
\hline 1994 & 65,72 & 56,43 & 3,73 & 398,33 \\
\hline 1995 & 72,36 & 56,43 & 3,73 & 398,33 \\
\hline 1996 & 72,36 & 56,43 & 3,73 & 398,33 \\
\hline 1997 & 80,00 & 56,43 & 3,73 & 398,33 \\
\hline 1998 & 99,58 & 56,43 & 3,73 & 398,33 \\
\hline 1999 & 108,21 & 56,43 & 3,73 & 398,33 \\
\hline 2000 & 115,85 & 107,22 & 3,78 & 398,33 \\
\hline 2001 & 125,80 & $107,22 *$ & 3,78 & 398,33 \\
\hline 2002 & 130,45 & $107,22 *$ & 3,15 & 398,33 \\
\hline 2003 & 139,75 & $107,22 *$ & 3,15 & 398,33 \\
\hline 2004 & 152,03 & 223,59 & 13,28 & 2683,13 \\
\hline 2005 & 157,01 & 243,25 & 17,92 & 2918,94 \\
\hline 2006 & 165,31 & 251,21 & 17,92 & 3014,54 \\
\hline 2007 & 170,28 & 264,49 & 17,92 & 3173,87 \\
\hline 2008 & 178,92 & 272,46 & 18,42 & 3269,47 \\
\hline 2009 & 185,19 & 335,48 & 19,32 & 4025,70 \\
\hline 2010 & 185,19 & 335,48 & 20,00 & 4025,70 \\
\hline 2011 & 189,83 & 296,61 & 20,02 & 3559,30 \\
\hline 2012 & 194,58 & 303,73 & 20,51 & 3644,74 \\
\hline 2013 & 198,09 & 311,33 & 20,03 & 3735,94 \\
\hline 2014 & 198,09 & 316,94 & 21,41 & 3803,33 \\
\hline 2015 & 198,09 & 316,94 & 21,41 & 3803,33 \\
\hline 2016 & 198,09 & 316,94 & 21,41 & 3803,33 \\
\hline 2017 & 205,07 & 316,94 & 21,41 & 3803,33 \\
\hline 2018 & 210,20 & 316,94 & 21,56 & 3803,33 \\
\hline 2019 & 214,83 & 328,11 & 22,17 & 3937,35 \\
\hline 2020 & 218,06 & 367,85 & 22,72 & 4035,84 \\
\hline
\end{tabular}

Source: own processing on the basic of statistical data

Act no. 595/2003 Coll. in which the non-taxable part for the taxpayer was determined, which changes depending on the growth of the subsistence minimum and which replaced 
the original, fixed non - taxable part for the taxpayer. (Konečná and Andrejovská, 2020) According to $\S 11$ of the Income Tax Act no. 595/2003 Coll. this non-taxable part for the taxpayer was determined to be 19,2 times the subsistence minimum valid on January 1 th each year. In accordance with the amendment to the Income Tax Act with effect from January 1th, 2011, the non-taxable parts apply only to active income, the income according to $\S 5$ and $\S 6$ section 1 and 2 of the Income Tax Act, ie for income from dependent activity and from business and other self-employed activity (not eg for rental income as it was until then). This provision applies in particular to all non-taxable parts, i.e. the non-taxable part for the taxpayer, the non-taxable part for the husband / wife and tax bonus for children .

During a calendar year, income from a dependent activity may be applied only to the non-taxable part of the taxable amount per taxpayer in the amount of one of the twelve (Carraro, 2006). Only after the end of the calendar year, when performing an annual settlement or when filing a tax return, other non-taxable parts may be applied, at the same time the non-taxable part may be applied in full, as an annual amount even if the taxpayer had no income in each month (Vašeková and Mateášová, 2017).

In 2007, the parliament decided to reduce the non-taxable part for the taxpayer. As part of anti-crisis measures taken in 2009-2010, the legislators increased the non-taxable part from 19,2 times to 22,5 times the subsistence level. Since 2011, the non-taxable part has returned to its original amount, at 19,2 times the subsistence level. From 2013 an upper limit was set on this non-taxable part for the taxpayer. The development of the non-taxable part for the taxpayer in relation to the subsistence minimum can be seen in figure no. 2 below

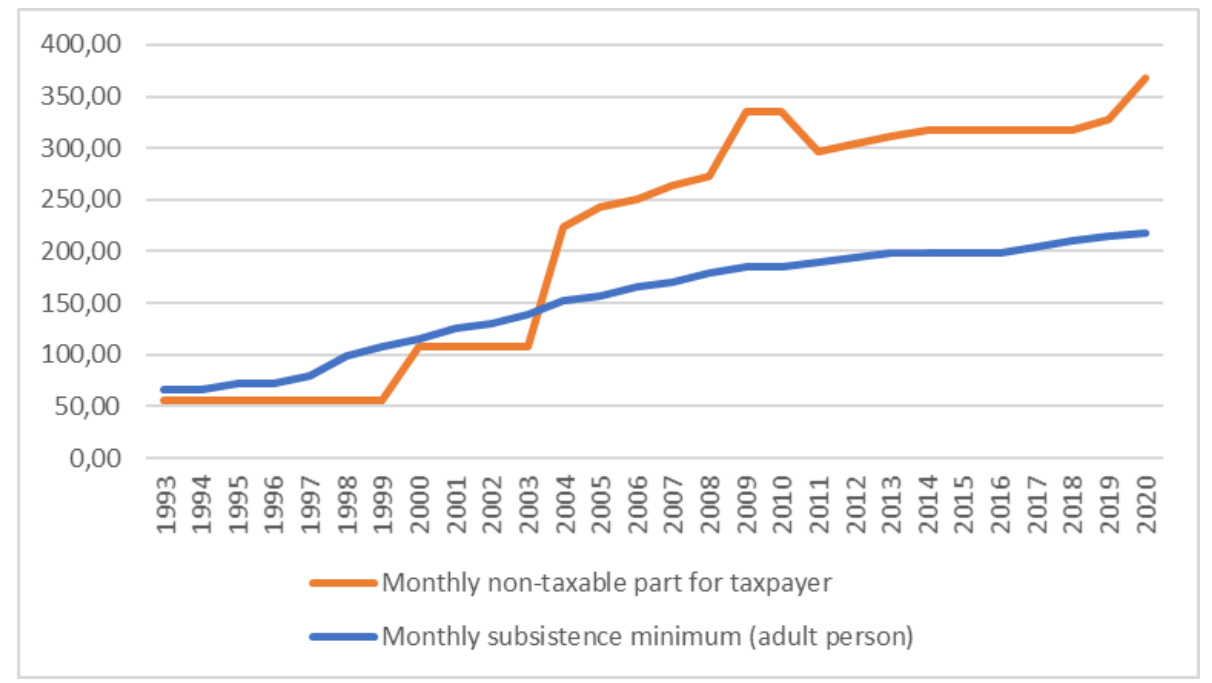

Figure 2. Monthly subsistence minimum vs. non-taxable part for taxpayer in eur

Source: own processing on the basic of statistical data

The non-taxable part for the taxpayer did not change from 2016 - 2017, due to the same amount of the subsistence minimum, and the same multiple of the subsistence minimum was also determined for the calculation of the non-taxable part in the given years. The first increase in the non-taxable part for the taxpayer can only be observed in 2018 due to an increase in the current standard of living. This increase caused the non-taxable part to increase by $0,70 \%$, which in turn affected the amount of the taxpayer's tax base when calculating income tax. The largest increase was in 2020, when the amount of the non taxable part for the taxpayer increased not only due to the increase in the subsistence minimum, but also due to the increase of the subsistence minimum from 19,2 times the 
subsistence minimum to 21 times the subsistence minimum per year. In 2020, the amount of the non-taxable part increased by 12,10\%, which represents EUR 39,73, which caused a further reduction in the tax base for the calculation of income tax and also reduced the tax burden on employees' wages.

The tax bonus for a child belongs to the group of tax benefits, as it reduces the calculated tax of the taxpayer, resp. during the year in which it reduces the monthly tax advance. (Chyzhevska et al., 2020) In 2004, the tax bonus replaced the non-taxable amount of the taxpayer income tax base for dependent children, which had applied from 1993 to 2003. Whereas the non-taxable amount reduced the taxpayer's tax base, the tax bonus only reduces the calculated tax. The non-taxable amount could reduce the tax base to a maximum of zero, but this is not the case with the tax bonus. If it is higher than the calculated tax liability, the difference is assessed to the taxpayer similarly to the tax overpayment and is paid to the taxpayer (Pavelka, 2015). The amount of the tax bonus is adjusted annually in connection with the increase in the subsistence minimum on July 1th of the given year. From 2015, the amount of the tax bonus has been adjusted on January 1th each year, ie. the amount of the tax bonus is uniform throughout the tax period. In the case of disabled children, a double deduction was applied when applying the non-taxable amount, the tax bonus for the child's disability is not taken into account. Since 2019, the amount of the tax bonus has depended on the age of the child.

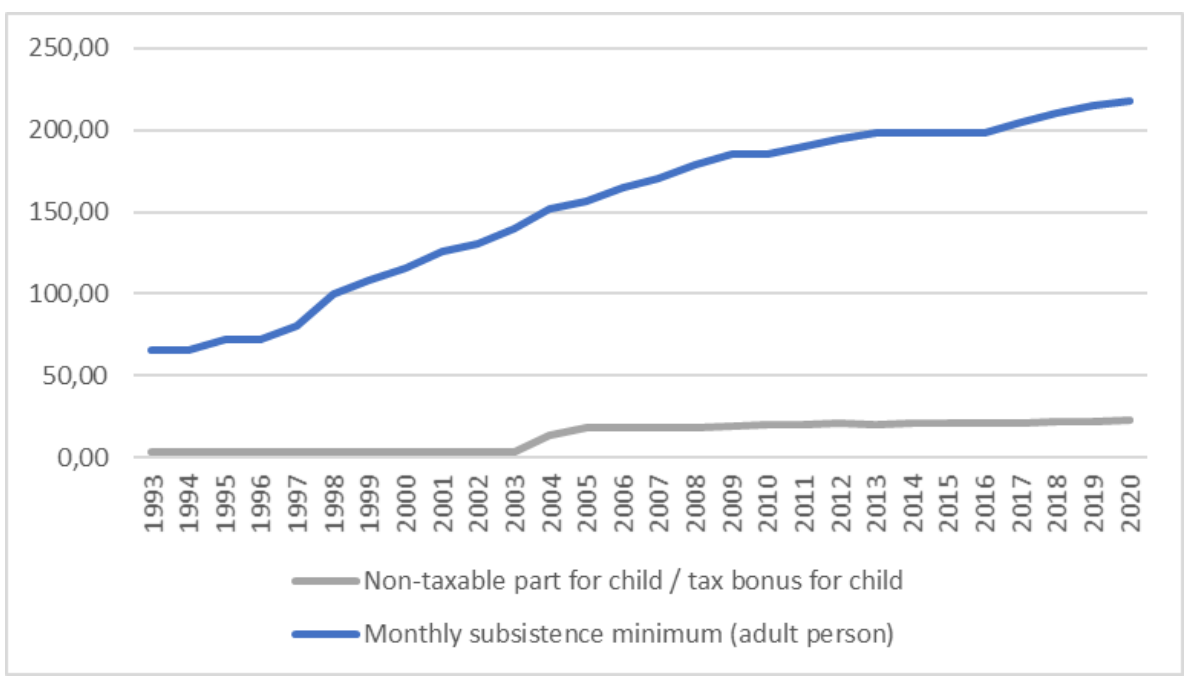

Figure 3. Monthly subsistence minimum vs. tax bonus or non-taxable part for child in eur

Source: own processing on the basic of statistical data

Figure 3 shows the development of the non-taxable part / tax bonus per child in relation to the subsistence minimum. As the system has changed over the years from the application of the non-taxable part to the child, which was deducted from the tax base to the application of the child tax bonus, which is deducted directly from the tax liability, the non-taxable parts in 1993-2004 were converted to tax savings in order to be compared in the graph with the tax bonus applied in the following years. Since 2019, the tax bonus has been differentiated according to the age of the child, for the purposes of compiling the chart, we took into account only the basic (i.e. the lowest) amount of the tax bonus. We can see in the graph that a more significant increase in the tax bonus only occurred in 2004, when the non-taxable amount per child was replaced by a tax bonus. Although the tax bonus has been adjusted annually, its amount does not reflect the growth of the subsistence minimum. 


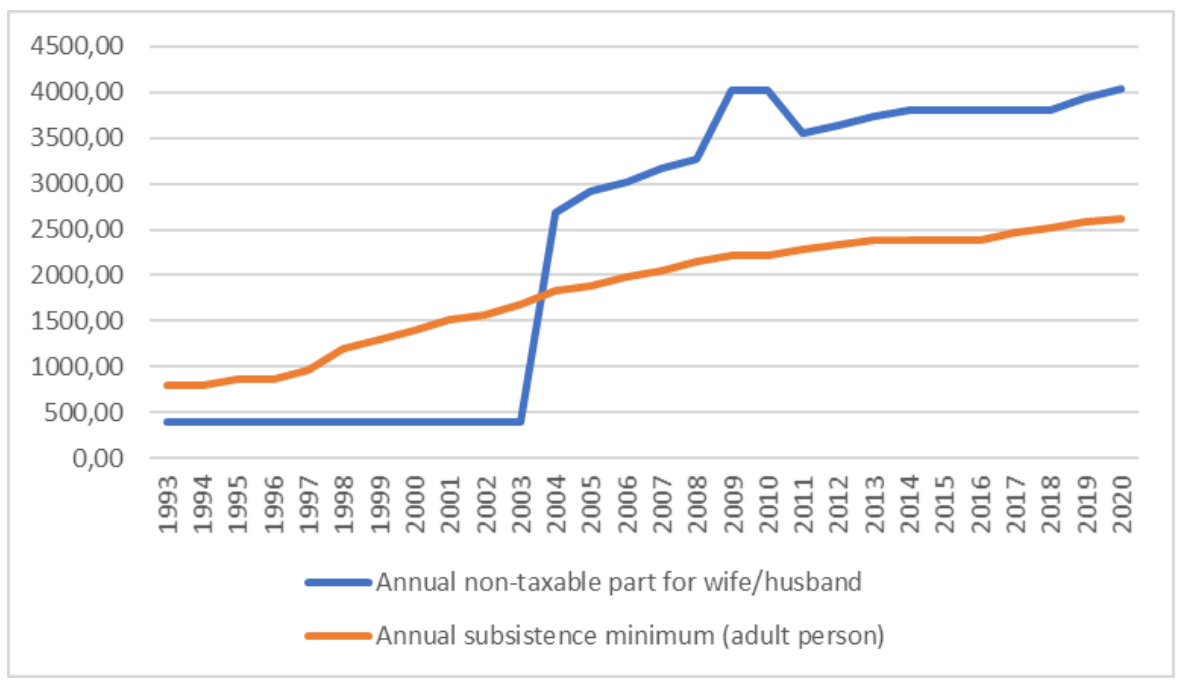

Figure 4. Monthly subsistence minimum vs. non-taxable part for taxpayer (husband/wife) in eur

Source: own processing on the basic of statistical data

In figure no. 4 the development of the non-taxable part for wife / husband in the years 1993 - 2021 is shown. A significant increase occurred in 2004, when this non-taxable part increased by a jump almost 7 times. Subsequently, its growth is linear, a more significant fluctuation occurred only in the years 2009 - 2010, when this non-taxable part temporarily increased as a consequence of anti-crisis measures. In 2013 additional conditions for the application of the non-taxable part to the child have been set - not only the absence of income for the husband / wife, but also the condition of caring for a child under 3 years and others. From year 2013 an upper limit has been set on this non-taxable part for husband / wife.

\section{Conclusion}

Based on the analysis and comparison of the growth of both the subsistence minimum and the average wage we can reject the first hypotheses and it can be stated that it is more appropriate to link the non-taxable part to the growth of the average wage and not to the growth of the subsistence minimum, thus maintaining the same share of net and gross wages for most incomes.

The non-taxable part for the taxpayer is the most frequently used option to reduce the tax base (Andrejovská, 2019). The conditions for its application have not changed significantly over the years (with the exception of the abolition of the increased amount for the disabled and the severely disabled). By providing for an increase in the non-taxable part as a result of the increase in the subsistence minimum, it has been ensured that the people with the lowest incomes are tax-advantaged. We can evaluate negatively only the determination of the level of income from which the non-taxable amount decreases, respectively the right to decrease the tax base it completely expires. With this measure, the parliament returned to the same effect of the regulation as in the case of the so-called millionaire tax from $1998-1999$, t. j. to the additional taxation of higher incomes. However, for the purposes of reducing this non-taxable part, the tax base is considered to be a tax base of approximately EUR 1660 ,- per month, which is less than 3 times the minimum wage and less than 1,5 times the average wage in the Slovak Republic. Based on the abovementioned claims we can reject also the second hypothesis. 
In connection with this non-taxable part per wife / husband, we can state that the number of taxpayers applying this non-taxable part has been significantly reduced by adding other conditions for its application since 2013. Also, as in the case of the nontaxable part per taxpayer, an upper limit of the taxpayer's tax base for its application has been set. This non-taxable part is gradually reduced at the taxpayer's tax level of approximately EUR 3165 ,- per month and the right to claim it expires at the tax base of approximately EUR 4 540,- per month.

The non-taxable part and the tax bonus per child are important for taxpayers. In recent years, however, the legislation and conditions of application have changed so often (even during the tax period) that this advantage for taxpayers - parents has become quite confusing. It is also difficult from the position of the employer and the state to ensure that only one of the parents applies the tax bonus and at the same time all other conditions are met (eg the condition of a child attending school, living in the same household). So the third hypothesis is also rejected plus this instrument gives ample scope for the illegal reduction of personal income taxes paid.

\section{Acknowledgements}

This article is an output of the project of the Scientific Grant Agency of the Ministry of Culture of the Slovak Republic and Slovak Academy of Sciences (VEGA) no. 1/0517/20 (2020-2022) "Virtual Cryptochains as a Relevant Tool to Eliminate Economic Crime."

\section{References}

1. Andrejovska, A. (2019). Effective Tax Rate in the Context of the Economic Determinants. Montenegrin Journal of Economics, 15(2), 31-40 .

2. Bicekova, A., Mihokova, L., \& Andrejovska, A. (2015). Revenue Analysis of Selfgoverning Regions in the Slovak Republic. Proceedings of the 5th Central European Conference in Regional Science (CERS) (pp. 76-87).

3. Aujean, M. (2014). Tax Competition and Tax Planning: What Solution for the EU? EC tax Review, 23(2), 62-63.

4. Bujňáková, M. (2017). Tax Law and its Status within a Legal System. Proceedings of the 4th International Baltic Conference on Financial Law - the Financial Law towards Challenges of the 21st Century (pp.273-280).

5. Carraro, L. (2006). Výpočet a využitie hranice absolútnej chudoby. MPSVR SR, Bratislava.

6. Chyzhevska, L., Romanenko, S., Timrienko, I., \& Zatoka, T. (2020). Taxation of NonProfit Religious Organizations in Ukraine. Academy of Accounting and Financial Studies Journal, 24(2).

7. Filipová, J., \& Valná, S. (1999.) Životné minimum. Bratislava: VÚPSVR.

8. Konečná, V., \& Andrejovská, A. (2020). Investor Decision-making in the Context of the Effective Corporate Taxation. E\&M Economics and Management, 23(1), 111-120.

9. Mihokova, L., Andrejovska, A., \& Martinkova, S. (2018). Tax Competitiveness of EU Member States in the Context of Corporate Taxation. Politicka ekonomie, 66(5), 588608.

10. Pavelka, T. (2015). The Minimum Wage in Visegrad Countries. Proceedings of the The 9th International Days of Statistics and Economics (pp. 1255-1261). 
11. Saric, I. (2014). Minimum Wage System in the European Union. Pravni Vjesnik, 30(2), 137-150.

12. Vašeková, M., \& Mateášová, M. (2017). Analysis of tax burden in the Slovak Republic with emphasis on depreciation. Proceedings of the 17th annual conference on finance and accounting (ACFA 2016). Springer.

13. vom Berge, P., \& Frings, H. (2020). High-impact minimum wages and heterogeneous regions. Empirical Economics, 59, 701-729.

14. Zeytinoglu, E., \& Akarim, Y. D. (2013). Financial Failure Prediction Using Financial Ratios: An Empirical Application on Istanbul Stock Exchange. Journal of Applied Finance \& Banking, 3(3), 107-116.

15. Zubal'ova, A. (2019). Eligibility of Social Factors in Taxation. Proceedings of the 13th International Scientific Conference on Public Economics and Administration (pp. 435443). 